\title{
Invariant Natural Killer T and Mucosal-Associated Invariant T Cells in Asthmatic Patients
}

\author{
Guillaume Lezmi ${ }^{1,2,3}$ and Maria Leite-de-Moraes ${ }^{2,3 *}$ \\ 'AP-HP, Hôpital Necker-Enfants Malades, Service de Pneumologie et d'Allergologie Pédiatriques, Paris, France, ${ }^{2}$ Université \\ Paris Descartes, Paris, France, ${ }^{3}$ Laboratory of Immunoregulation and Immunopathology, INEM (Institut Necker-Enfants \\ Malades), CNRS UMR8253 and INSERM UMR1151, Paris, France
}

OPEN ACCESS

Edited by:

Luc Van Kaer

Vanderbilt University,

United States

Reviewed by:

Chiaki Iwamura,

National Institutes of Health

$(\mathrm{N} / \mathrm{H})$, United States

Seddon Y. Thomas,

National Institute of Environmental

Health Sciences (NIEHS),

United States

Rosemarie DeKruyff,

Stanford University, United States

*Correspondence:

Maria Leite-de-Moraes maria.leite-de-moraes@ parisdescartes.fr

Specialty section: This article was submitted to T Cell Biology,

a section of the journal

Frontiers in Immunology

Received: 28 April 2018

Accepted: 17 July 2018

Published: 30 July 2018

Citation:

Lezmi G and Leite-de-Moraes M (2018) Invariant Natural Killer T and

Mucosal-Associated Invariant

$T$ Cells in Asthmatic Patients.

Front. Immunol. 9:1766. doi: 10.3389/fimmu.2018.01766
Recent studies have highlighted the heterogeneity of asthma. Distinct patient phenotypes (symptoms, age at onset, atopy, and lung function) may result from different pathogenic mechanisms, including airway inflammation, remodeling, and immune and metabolic pathways in a specific microbial environment. These features, which define the asthma endotype, may have significant consequences for the development and progression of the disease. Asthma is generally associated with Th2 cells, which produce a panel of cytokines (IL-4, IL-5, IL-13) that act in synergy to drive lung inflammatory responses, mucus secretion, IgE production, and fibrosis, causing the characteristic symptoms of asthma. In addition to conventional CD4+ $\mathrm{T}$ lymphocytes, other T-cell types can produce Th2 or Th17 cytokines rapidly. Promising candidate cells for studies of the mechanisms underlying the pathophysiology of asthma are unconventional T lymphocytes, such as invariant natural killer T (iNKT) and mucosal-associated invariant T (MAIT) cells. This review provides an overview of our current understanding of the impact of iNKT and MAIT cells on asthmatic inflammation, focusing particularly on pediatric asthma.

Keywords: asthma, NKT cells, mucosal-associated invariant T cells, children, patients, CD1d, MR1, Th2 cells

\section{INTRODUCTION}

Asthma is now considered to encompass different conditions characterized by common symptoms (wheeze, cough, shortness of breath, and chest tightness), variable degrees of airflow limitation, and different pattern of inflammation. Most patients with asthma have an eosinophilic infiltration of the airways, associated with increased production of type 2 cytokines including IL-4, IL-5, IL- 13 secreted by Th2 cells, together with allergic comorbidities (1). However, around $50 \%$ of adults with asthma do not fall into this description (2). Asthmatic patients with a neutrophil-high signature were described in both adults and children (3-5). This neutrophilic-predominant endotype is less well understood than the Th2 endotype and may be related to the activation of the IL-17 pathway $(1,6)$. Intriguingly, despite eosinophilic airway inflammation is a key feature of severe asthma in schoolchildren, there is no clear evidence for a Th2 type cytokine signature in bronchial mucosa or bronchoalveolar lavages in that population $(7,8)$. Alternative mechanisms may, therefore, be involved in the pathogenesis of asthma in this group. Recent studies have suggested the potential role of unconventional $\mathrm{T}$ cells, such as invariant natural killer T (iNKT) and mucosal-associated invariant T (MAIT) cells in asthma pathogenesis. These T lymphocytes usually reside in the tissues, including those of the airways and can respond rapidly to stimuli by producing Th2 and Th17 cytokines. Here, we review the field of asthma immunity, focusing on the role of iNKT and MAIT cells in asthmatic patients. 


\section{iNKT CELLS}

The major characteristic of iNKT lymphocytes is their expression of $\mathrm{T}$ cell receptors of limited diversity recognizing lipid antigens presented by the non-polymorphic MHC-like molecules, CD1d $(9,10)$. iNKT cells express an invariant TCR $\alpha$ chain, V $\alpha 14-J \alpha 18$ (or TRAV11 TRAJ18) in mouse, and Vo24-J $\alpha 18$ (or TRAV10 TRAJ18) in humans, together with a limited set of TCR $\beta$ chains $(10,11)$. The invariant TCR $\alpha$ chains of mice and human are very similar, enabling the iNKT cells to recognize the same glycolipids in both species. A classic example is provided by $\alpha$-galactosylceramide ( $\alpha$-GalCer), an antigen capable of stimulating both mouse and human iNKT cells $(12,13) . \alpha$-GalCer and its analog, PBS57, are currently used as antigens for the production of a CD1d-tetramer complex capable of specifically identifying iNKT cells (14). iNKT lymphocytes respond rapidly to specific lipid antigens, in a TCR-dependent manner, but they also respond to pro-inflammatory cytokines $(12,15,16)$. Indeed, IL-12 and IL-18 induce the production of IFN $\gamma$, whereas IL- $1 \beta$ and IL-23 will promote the secretion of IL-17A (or IL-17) and IL-22 $(17,18)$. Further, iNKT cells have been shown to express IL-25 (or IL-17E), thymic stromal lymphopoietin, and IL-33 receptors that will favor their secretion of IL-4, IL-13, and IFN $\gamma$ (19-22). Human iNKT cells require TGF $\beta$ for the production of IL-17 and IL-22 (23). TCR-dependent and TCR-independent pathways can act in synergy to stimulate iNKT cells more strongly $(15,24)$.

The thymic differentiation of iNKT cells is tightly controlled. At least three major iNKT cell subsets mature in the thymus, the iNKT1 (IFN $\gamma$ and IL-4 producers), the iNKT2 (IL-4 and IL-13 producers), and the iNKT17 (IL-17 and IL-22 producers) (25-28). Maturation in the thymus is regulated by the Slam-Associated Protein (29), the transcription factors PLZF, Egr2, ThPOK, Runx1, and ROR $\gamma \mathrm{t}$, the microRNA Let-7, and the cytokine IL-7 (30-38). iNKT cells undergo several maturation steps [see Ref. $(10,35)$ for more information], before migrating to peripheral organs as $\mathrm{CD} 4^{+} \mathrm{CD} 8^{-}$and double-negative $\left(\mathrm{CD} 4^{-} \mathrm{CD} 8^{-}\right)$cells. In humans, there is also a $\mathrm{CD} 4^{-} \mathrm{CD} 8^{+}$subset (39). iNKT cells are mostly resident in tissues, where they can "patrol" to identify threats to the body. For instance, these cells have been shown to perform an intravascular immune surveillance function in the liver, spleen, and lung (40-43). The primary function of iNKT cells is to protect the host from infections $(24,44,45)$. However, in some conditions, iNKT cell activation favors tissue injury, including lung (Figure 1), as discussed below.

\section{iNKT Cells and Murine Asthma Models}

Mouse models are widely used to help clarify the role of iNKT cells in asthma. Studies initially focused on allergic asthma, with ovalbumin (OVA) as the allergen, associated with aluminum hydroxide as adjuvant, for the systemic immunization followed by intranasal (i.n.) OVA challenge. First analysis showed no major difference in the severity of allergic airway inflammation in $\beta_{2}$ microglobulin $\left(\beta_{2} \mathrm{~m}\right)^{-/-}$and $\mathrm{CD} 1 \mathrm{~d}^{-/-}$mice, which lack iNKT cells (46-48). However, other studies reported that iNKT cell-deficient $\left(\mathrm{J} \alpha 18^{-/-}\right.$and $\left.\mathrm{CD} 1 \mathrm{~d}^{-{ }^{--}}\right)$mice had attenuated asthma symptoms including airway hyperresponsiveness (49), airway eosinophilia, Th2 inflammation, and OVA-specific
anti-IgE production $(50,51)$. The adoptive transfer of IL-4- and IL-13-producing iNKT cells restored the asthma severity, demonstrating that iNKT cells favored allergic asthma symptoms through the production of these cytokines $(50,51)$. iNKT cells did not recognize OVA as an antigen, but their ability to promote lung inflammation was reduced by the treatment of mice with anti-CD1d antibodies, indicating that endogenous lipidic antigens stimulated the iNKT cells (50). More recently, another study comparing distinct iNKT cell-deficient mice strains $\left(\beta_{2} \mathrm{~m}^{-/-}\right.$and $\left.\mathrm{CD}^{2} \mathrm{~d}^{--}\right)$reported that NKT cells were dispensable for T celldependent allergic airway inflammation (52), even though AHR was not analyzed.

A possible reason to explain the discrepancies between studies concerning the implication of iNKT cells in asthma severity is that, in addition to iNKT cells, type II NKT cells were also absent in $\beta_{2} \mathrm{~m}^{-/-}$and $\mathrm{CD}_{1} \mathrm{~d}^{-/-}$mice $(53,54)$, while $\beta_{2} \mathrm{~m}^{-/-}$mice also lack CD8 T cells. Then, it is not excluded that the absence of type II NKT and $C D 8^{+} \mathrm{T}$ cells could influence the effect of iNKT cells in asthma severity. Another point is that asthma symptoms are more severe in $129 / \mathrm{Sv}$ mice compared to $\mathrm{BALB} / \mathrm{c}$ and $\mathrm{C} 57 \mathrm{BL} / 6$ animals (55). The iNKT cell-deficient mice cited here $\left(\beta_{2} \mathrm{~m}^{-/-}, \mathrm{CD}^{-1-} \mathrm{d}^{-/}\right.$, and $\mathrm{J} \alpha 18^{-/-}$mice) were created on a $129 / \mathrm{Sv}$ background. Some results showing no significant differences in airway eosinophilia used $129 / \mathrm{Sv} \times \mathrm{C} 57 \mathrm{BL} / 6 \mathrm{CD}^{-1 /}{ }^{-1}$ mice (47), while those describing $\mathrm{CD}^{-\mathrm{d}^{-/}}$and $\mathrm{J} \alpha 18^{-/-}$mice as more resistant to asthma used $\mathrm{CD}^{\mathrm{d}} \mathrm{d}^{-/-}$and $\mathrm{J} \alpha 18^{-/-}$backcrossed with BALB/c animals (51). In our hands, Jo18 $8^{--}$(backcrossed at least 10 times in C57BL/6) presented lower allergen-induced airway inflammation and AHR than controls (50). Recently, Kronenberg's team created a new mouse strain deficient for iNKT cells. These mice presented no airway eosinophilia and significantly less pulmonary resistance in response to OVA challenge than did their wild-type (WT) counterparts (56). Hence, the discrepancies reported may also result from a possible low number of backcross of the knockout mice used. Finally, the microbiota differences between the animal houses where the studies were performed cannot be excluded. In this context, an elegant study by Blumberg's team showed that iNKT cells accumulated in the lung and in the colonic lamina propria in germ-free (GF) mice, rendering these animals more susceptible to OVA-induced asthma and oxazolone-induced colitis (57). The colonization of neonatal GF mice with a normal flora or Bacteroides fragilis decreased the number of iNKT cells and protected the mice against these diseases, clearly establishing a link between iNKT cells, the microbiota, and disease $(57,58)$.

These studies were highly informative but were designed to analyze a specific allergic asthma model. They, therefore, underestimated the complexity of asthma pathogenesis. It was subsequently shown that $\alpha$-GalCer, the cognate antigen for iNKT cells, protects sensitized mice against asthma symptoms when administered $1 \mathrm{~h}$ before the first challenge (59). The mechanisms involved are dependent on IFN $\gamma$ production by $\alpha$-GalCer-stimulated iNKT cells (59). In another context, $\alpha$-GalCer, administered i.n. at the time of sensitization, was found to act as an adjuvant, enhancing asthma symptoms (42). This study echoed those in non-human primates showing that the administration of $\alpha$-GalCer alone induces AHR in monkeys (60). The iNKT cells are resident mostly in the intravascular space 


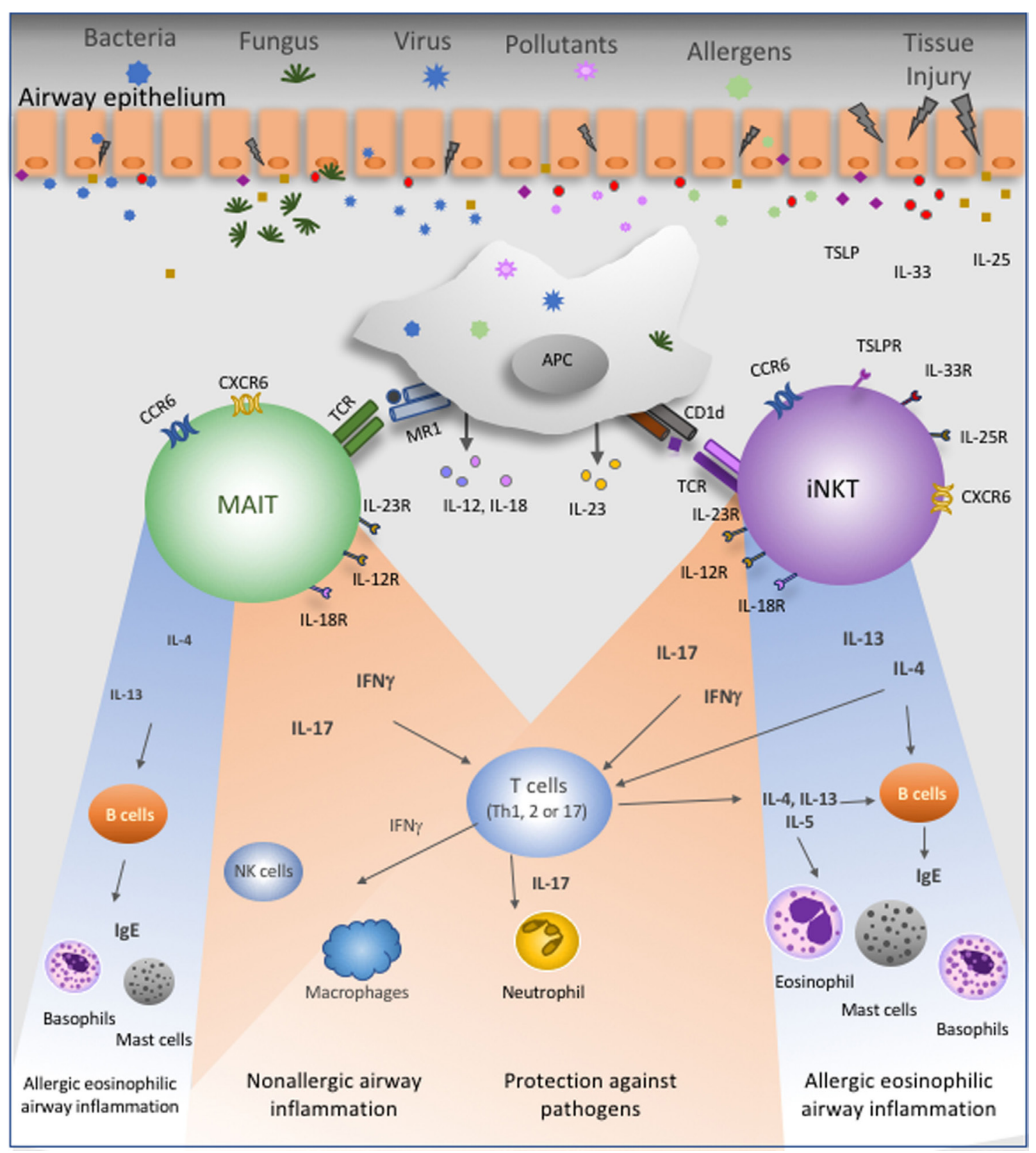

FIGURE 1 | Proposed roles of mucosal-associated invariant T (MAIT) and invariant natural killer T (iNKT) cells in the lung. These unconventional T lymphocytes are present in the lung at steady state and express several chemokine- and interleukin-receptors. Bacteria, fungus, virus, pollutants, and airway allergens will directly or indirectly stimulate MAIT and iNKT cells. Cytokines produced by epithelial cells, namely, IL-25, IL-33, and thymic stromal lymphopoietin, could activate these cells. Antigen-presenting cells (APC) present antigens to MAIT and INKT cells in the context of MR1 and CD1d molecules, respectively. Activated APC produce IL-12, IL-18, and IL-23 that will stimulate MAIT and/or INKT cells. Following TCR-dependent or TCR-independent activation, MAIT and INKT cells secrete IFN $\gamma$, IL-17, IL-4, or IL-13. IFNy contributes to lung protection and promotes potential protective Th1 responses against asthma. IL-17, in turn, could have a dual effect since it is known that this cytokine promotes neutrophils recruitment and activation to protect lung from injury, but IL-17 can also enhance neutrophilic asthma severity. Finally, IL-4 and IL-13 will favor Th2 immune responses and then amplify allergic eosinophilic airway inflammation.

rather than in the pulmonary tissue itself, and they are rapidly mobilized after exposure to airborne lipid antigen, to which they respond by the secretion of cytokines (42). Thus, different lipid antigens in the airways, unrecognized by conventional $\mathrm{T}$ cells, may amplify airway inflammation by acting on iNKT cells.
Other asthma models have recently been used to investigate the role of iNKT cells. Intranasal administration of the natural House Dust Mite allergen without adjuvant has been shown to induce iNKT cell recruitment in the lung. The iNKT cells were stimulated via OX40-OX40 ligand interactions to generate 
a pathogenic Th2 cytokine environment (61). In this model, iNKT-deficient mice displayed significantly lower levels of pulmonary inflammation than WT mice (61). iNKT cells were further implicated in the model of asthma induced by Aspergillus fumigatus (62). This fungus, which is associated with a severe form of asthma, expresses asperamide-B, a glycolipid specifically recognized by both human and mouse iNKT cells (62). The i.n. administration of $A$. fumigatus- or asperamide-B rapidly induces AHR, by activating pulmonary iNKT cells in an IL-33-ST2- and IL-4/IL-13-dependent manner (62).

Overall, these findings indicate that iNKT cells promote allergic asthma inflammation and AHR principally through the secretion of IL-4 and IL-13. The Th2 paradigm explains many features of asthma, but this disease is not limited to pro-Th2 allergic immune responses and may also include a number of different phenotypes, such as neutrophilic asthma (63-65). In this context, the i.n. administration of $\alpha$-GalCer activates IL-17-secreting iNKT (iNKT17) cells, which, in turn, recruit neutrophils to the airways (25). iNKT17 cells are also required for the pathogenic mechanism responsible for disease severity in the model of asthma induced by ozone, a major air pollutant (66). These findings indicate that iNKT2 and iNKT17 cell populations may contribute to asthma inflammation in different ways.

\section{iNKT Cells and Asthmatic Patients}

Several studies have analyzed the possible implication of iNKT cells in the physiopathology of human asthma. Studies analyzing the frequency of iNKT cells in the [bronchoalveolar-lavage fluid (BALF)] or bronchial tissues of asthmatic patients have reported discordant results (67-70). The study of Akbari et al. (68) found that about $60 \%$ of the pulmonary $\mathrm{CD} 4{ }^{+} \mathrm{CD}^{+} \mathrm{T}$ cells in adult patients with moderate-to-severe persistent asthma were iNKT cells. These results were not reproduced by Vijayanand et al. (69), who found that up to $2 \%$ of the T cells obtained from airway biopsy, BALF, and sputum induction from subjects with mild or moderately severe asthma were iNKT cells. The study of Thomas et al. (71) also observed less than $2 \%$ of iNKT cells among gated T lymphocytes from BALF of asthmatic patients. Of note, further analysis from the initial group have demonstrated that only a small fraction of $\mathrm{T}$ cells in the lung of adult asthmatic patients were iNKT cells (72). In our hands (73), iNKT cells accounted for less than $1 \%$ of $\mathrm{T}$ cells in BALF from severe asthmatic children. The discrepancies with the first study (68) could be due to the limited number of samples, the heterogeneity of the cohort, or to non-specific staining of cells in BALF, as suggested by the study of Thomas et al. (71).

It was showed that the frequency of iNKT cells in the blood of adult asthmatic patients was similar to that in blood from control donors (74). Further, it was suggested that pro-Th2 iNKT cells may be particularly frequent in blood from asthmatic patients, and that these cells was associated with lung function (67). Our previous study indicated that the percentage of peripheral blood iNKT cells did not differ significantly between asthmatic children classified as exacerbators ( 1 or more severe exacerbations in the last 12 months) and those classified as non-exacerbators (75). Similarly, it has recently been reported that there is no relationship between the frequency of iNKT cells and that of IL-4- or
IFN $\gamma$-producing iNKT cells in the blood of 1-year-old children and asthma-related clinical outcomes at the age of 7 years (76).

There is now a consensus that a limited number of iNKT cells is present in the BALF of adults and pediatric patients with severe asthma. However, several questions remain unanswered: Is the presence of iNKT cells in the BALF associated with specific asthma endotypes? What role do iNKT cells play in the pathophysiology of asthma? Further studies are therefore required to characterize the mechanisms by which iNKT cells could contribute to asthma.

\section{MAIT CELLS}

Invariant natural killer $\mathrm{T}$ and MAIT cells may be considered to be "twins" in several respects. Like iNKT cells, most MAIT cells express an invariant TCR $\alpha$ chain (V $\alpha 7.2-\mathrm{J} \alpha 33$ or TRAV1-2TRAJ33) and a small number of TCR $\beta$ chains (77). MAIT cells are restricted by the MHC class I-related molecule MR1 and recognize microbial-derived vitamin B2 (riboflavin) metabolites, such as the 5-(2-oxopropylideneamino)-6-D-ribitylaminouracil (5-OP-RU) (78). The endogenous ligands able to either select MAIT cells in the thymus or to potentially stimulate these cells in peripheral lymphoid organs remain to be defined.

Mucosal-associated invariant T cells, similar to iNKT cells, develop in the thymus, where they became functionally competent and able to produce IFN $\gamma, \mathrm{TNF} \alpha$, and IL-17 in response to stimulation (79). MAIT cells produce low-to-moderate levels of IL-4 and IL-13 when stimulated (80-83). Thymic MAIT development is also directed by the transcription factor PLZF and is dependent on microRNAs $(79,84)$. Human MAIT cells are CD8 ${ }^{+}$, $\mathrm{CD} 4^{+}$, or double-negative $\left(\mathrm{CD} 4^{-} \mathrm{CD} 8^{-}\right)$and express high levels of CD161 and IL-18R $\alpha(85)$. MAIT cells can be activated in a TCRdependent and -independent manner. In the latter situation, they can be stimulated by pro-inflammatory cytokines, such as IL-7, IL-12, IL-18, and IL-23 $(29,86,87)$. Indeed, MAIT cells, in addition to IL-18R $\alpha$, can also express IL-7R $\alpha$, IL-23R, IL-12R $\beta 1$, CCR5, CXCR6, CCR6 $(83,84,88,89)$. These receptors will allow the activation of MAIT cells by IL-7, IL-12, IL-18, and IL-23 and their migration to peripheral tissues.

Despite their striking similarities, iNKT and MAIT cells also differ in several important ways. Unlike iNKT cells, MAIT cells are rare in conventional laboratory mouse strains and abundant in humans. In healthy individuals, MAIT cells account for up to $10 \%$ of peripheral blood $\mathrm{T}$ cells and are numerous in the gut, lung, and liver $(49,85,89)$. The expansion of the MAIT cell population in response to commensal flora antigens explains their abundance in mucosal tissues, in which they are involved in antimicrobial responses (49). Their presence in the liver may be explained by the constant exposure of this organ to bacterial products absorbed from the gut. There is a clear causal relationship between the number of MAIT cells and the presence and the diversity of the commensal flora, as shown by the absence of MAIT cells from the peripheral organs of GF mice (49).

\section{MAIT Cells and Infections}

In addition to the commensal flora, pathogens may also stimulate MAIT cells, which play a crucial role in antimicrobial defenses, through the secretion of IFN $\gamma, \mathrm{TNF} \alpha$, and IL-17 and the killing 
of target cells through the production of cytotoxic perforin and granzyme B molecules (29, 87, 90). MAIT cell analysis, in both humans and in experimental models, has been greatly facilitated by the use of antigen-loaded MR1 tetramers $(83,84)$. Experimental studies in non-human primates have reported the activation of circulating MAIT cells in response to Bacillus Calmette-Guerin vaccination and Mycobacterium tuberculosis infection (91). MAIT cells from the spleen of these macaques produced IFN $\gamma, \mathrm{TNF} \alpha$ in response to stimulation by Escherichia coli in a TCR-dependent manner (91). Intranasal inoculation with Salmonella typhimurium in mice induced a striking enrichment in IL-17-producing MAIT cells in the lungs (92). The response of MAIT cells to lung infection with $S$. typhimurium was rapid and dependent on the MR1 presentation of riboflavin biosynthesisderived bacterial ligands (92). These findings are consistent with previous reports indicating that patients infected with mycobacteria have many more MAIT cells in the infected lung and fewer MAIT cells in the blood than uninfected controls $(93,94)$.

Infections with viruses, such as dengue virus, hepatitis $C$ virus, influenza A virus, and HIV-1 can activate human MAIT cells. MAIT cells do not recognize virus antigens, because no riboflavin metabolites are found in host cells or viruses (78), but they may be activated by cytokines produced during viral infection, such as IL-18 in synergy with IL-12, IL-15, and/or IFN $\alpha / \beta(29,95)$. Activated MAIT cells during virus infections robustly secrete IFN $\gamma$ and granzyme B $(29,95)$.

Mucosal-associated invariant $\mathrm{T}$ cells have also been implicated in non-infectious diseases. Several studies have reported large decreases in MAIT cell number in the peripheral blood of patients with the following diseases: antineutrophil cytoplasm antibody-associated vasculitis, chronic kidney disease, Crohn's disease, ulcerative colitis, newly diagnosed and relapsed multiple myeloma, obesity and type 2 diabetes (96-100). However, the mechanisms by which MAIT cells influence these human diseases remain to be elucidated.

\section{MAIT Cells and Adult Asthmatic Patients}

Despite the prevalence of MAIT cells in the lung, and their involvement in airway infections, very little is known about the possible role of these cells in asthma. MAIT cells are detected in human fetal lung and are numerous in the lungs of adult rhesus macaques $(91,101)$, consistent with a protective role against infections in this organ. The frequency of MAIT cells is significantly lower in the peripheral blood, sputum, and bronchial biopsy specimens of asthmatic patients than in control subjects (102). The percentage of MAIT cells in BALF does not differ significantly between these two groups (102). A re-analysis of the results, comparing patients with mild, moderate, or severe asthma to healthy donors, showed that the lower frequency of MAIT cells was significant only in the peripheral blood and sputum of patients with moderate or severe asthma (102). The results of this study suggest that the frequency of MAIT cells is negatively correlated with clinical severity. Furthermore, MAIT cell frequency is associated with serum vitamin D3 concentrations and the use of oral corticosteroids. Proof of concept for the association between corticosteroid use and MAIT frequencies was provided by the demonstration of a decrease in the frequency of circulating MAIT cells in 12 patients with moderate asthma treated with oral corticosteroids for seven days (102). It remains to elucidate whether corticosteroids may modify MR1 expression and MAIT cell activation. Some drugs can influence antigen presentation by MR1 molecules. For instance, doxofylline, a bronchodilator used to treat asthma, is known to upregulate MR1 expression weakly, but does not act as a MAIT cell agonist (103). Thus, some of the drugs currently used in asthma treatment may influence MAIT cell functions.

Mucosal-associated invariant $\mathrm{T}$ cells are present and can be activated in the lung (Figure 1). However, to date, there is no evidence indicating that MAIT cells could recognize via their TCR any airway allergens or pollutants potentially implicated on asthma. Consequently, MAIT cells could be activated either directly by endogenous compounds presented by MR1 molecules or indirectly by pro-inflammatory cytokines present in the lung of asthmatics, namely IL-1 $\beta$, IL-7, and IL-23 $(104,105)$. These two possibilities are not mutually exclusive. Of note, asthma exacerbations are frequently associated with virus infections (104), which indirectly activate MAIT cells through the induction of proinflammatory cytokines $(29,95)$. MAIT cells then activated will secrete IFN $\gamma$ and/or IL-17. Knowing that MAIT cells secrete low levels of Th2 cytokines, namely IL-4 and IL-13 (80-82, 88-90, 106), we cannot exclude the possibility that these lymphocytes will promote Th2 responses (Figure 1). However, as discussed before, asthma is a complex pathology that is not restricted to overproduction of Th2 cytokines. Further, IL-17 and IFN $\gamma$ production were associated with asthma severity in some steroid-resistant patients $(107,108)$. Overall, these studies have provided a basis for further analyses of the role of MAIT cells in asthma, potentially on steroid-resistant asthma, and of the mechanisms by which these cells affect asthma severity.

\section{MAIT Cells and Pediatric Asthmatic Patients}

Asthma is frequent in children, but little is known about the possible influence of MAIT cells on the pathophysiology of this disease in childhood. We recently reported a similar frequency of circulating MAIT cells between exacerbators and nonexacerbators, in a population of asthmatic children (75). However, the frequency of IL-17-producing MAIT (MAIT-17) cells was found to be positively correlated with the number of severe exacerbations and negatively correlated with the asthma control test (ACT) score (75). No significant modification of the frequency of IFN $\gamma$-producing MAIT cells was observed (109). These findings indicate a possible association of MAIT-17 cells with asthma symptoms. Interestingly, higher levels of IL-17 production by MAIT cells have been observed in a number of non-infections pathologies, such as obesity, type 2 diabetes, and inflammatory bowel disease $(99,100)$, indicating that mechanisms other than infections may favor IL-17 production by MAIT cells.

Another recent study reported that an association between a high frequency of circulating MAIT cells at 1 year of age and a lower risk of asthma by the age of 7 years (76). Furthermore, this high frequency of MAIT cells was correlated with higher frequency of IFN- $\gamma$-producing $\mathrm{CD} 4^{+} \mathrm{T}$ cells, indicating a possible protective effect of MAIT cells as children grow older (76). 
IL-17 production by MAIT cells did not correlate with asthma in this study (110). Taken together, the results of these two studies suggest that MAIT-17 cells may be associated with asthma symptoms, whereas pro-Th1 MAIT cells may promote protection $(75,76)$.

\section{CONCLUSION}

Our understanding of the biology of both iNKT and MAIT cells and their role in asthma has increased considerably in recent years (Figure 1). As a result, many new questions have been raised concerning the mechanisms by which iNKT and MAIT cells could promote human severe asthma. For example, time may be an important element, because asthma often begins early in childhood, when the number and functional properties of lung iNKT and MAIT cells may be fixed. Studies

\section{REFERENCES}

1. Muraro A, Lemanske RF Jr, Hellings PW, Akdis CA, Bieber T, Casale TB, et al. Precision medicine in patients with allergic diseases: airway diseases and atopic dermatitis-PRACTALL document of the European Academy of Allergy and Clinical Immunology and the American Academy of Allergy, Asthma \& Immunology. J Allergy Clin Immunol (2016) 137(5):1347-58. doi:10.1016/j.jaci.2016.03.010

2. Wenzel SE. Asthma phenotypes: the evolution from clinical to molecular approaches. Nat Med (2012) 18(5):716-25. doi:10.1038/nm.2678

3. Andersson CK, Adams A, Nagakumar P, Bossley C, Gupta A, De Vries D, et al. Intraepithelial neutrophils in pediatric severe asthma are associated with better lung function. J Allergy Clin Immunol (2017) 139(6):1819-29. e11. doi:10.1016/j.jaci.2016.09.022

4. Lezmi G, Gosset P, Deschildre A, Abou-Taam R, Mahut B, Beydon N, et al. Airway remodeling in preschool children with severe recurrent wheeze. Am J Respir Crit Care Med (2015) 192(2):164-71. doi:10.1164/ rccm.201411-1958OC

5. Ricciardolo FLM, Sorbello V, Folino A, Gallo F, Massaglia GM, Favata G, et al. Identification of IL-17F/frequent exacerbator endotype in asthma. J Allergy Clin Immunol (2017) 140(2):395-406. doi:10.1016/j.jaci.2016.10.034

6. Lambrecht BN, Hammad H. The immunology of asthma. Nat Immunol (2015) 16(1):45-56. doi:10.1038/ni.3049

7. Bossley CJ, Fleming L, Gupta A, Regamey N, Frith J, Oates T, et al. Pediatric severe asthma is characterized by eosinophilia and remodeling without $\mathrm{T}(\mathrm{H}) 2$ cytokines. J Allergy Clin Immunol (2012) 129(4):974-82.e13. doi:10.1016/j. jaci.2012.01.059

8. Fitzpatrick AM, Higgins M, Holguin F, Brown LA, Teague WG; National Institutes of Health/National Heart L, Blood Institute's Severe Asthma Research P. The molecular phenotype of severe asthma in children. J Allergy Clin Immunol (2010) 125(4):851-7.e18. doi:10.1016/j.jaci.2010.01.048

9. Bendelac A, Savage PB, Teyton L. The biology of NKT cells. Annu Rev Immunol (2007) 25:297-25336. doi:10.1146/annurev.immunol.25.022106.141711

10. Godfrey DI, Stankovic S, Baxter AG. Raising the NKT cell family. Nat Immunol (2010) 11(3):197-206. doi:10.1038/ni.1841

11. Kronenberg $M$. When less is more: $T$ lymphocyte populations with restricted antigen receptor diversity. J Immunol (2014) 193(3):975-6. doi:10.4049/ jimmunol.1401491

12. Zajonc DM, Cantu C III, Mattner J, Zhou D, Savage PB, Bendelac A, et al. Structure and function of a potent agonist for the semi-invariant natural killer T cell receptor. Nat Immunol (2005) 6(8):810-8. doi:10.1038/ni1224

13. Kawano T, Cui J, Koezuka Y, Toura I, Kaneko Y,MotokiK, etal.CD1d-restricted and TCR-mediated activation of valpha14 NKT cells by glycosylceramides. Science (1997) 278(5343):1626-9. doi:10.1126/science.278.5343.1626

14. Matsuda JL, Naidenko OV, Gapin L, Nakayama T, Taniguchi M, Wang CR, et al. Tracking the response of natural killer T cells to a glycolipid antigen using CD1d tetramers. J Exp Med (2000) 192(5):741-54. doi:10.1084/jem. 192.5.741 conducted in children may, therefore, be crucial. Analyses of circulating iNKT and MAIT cells, as biomarkers, may be informative, but data for BALF and bronchial biopsies are still lacking. Finally, detailed analyses of the frequency and functional subsets of these cells in the context of different asthma endotypes may be crucial for the development of new therapeutic approaches.

\section{AUTHOR CONTRIBUTIONS}

GL and MLM wrote the manuscript.

\section{FUNDING}

This work was supported by funds from INSERM, CNRS, and Paris Descartes University, Paris, France.

15. Brennan PJ, Brigl M, Brenner MB. Invariant natural killer T cells: an innate activation scheme linked to diverse effector functions. Nat Rev Immunol (2013) 13(2):101-17. doi:10.1038/nri3369

16. Kumar A, Suryadevara N, Hill TM, Bezbradica JS, Van Kaer L, Joyce S. Natural killer T cells: an ecological evolutionary developmental biology perspective. Front Immunol (2017):81858. doi:10.3389/fimmu.2017.01858

17. Leite-De-Moraes MC, Hameg A, Arnould A, Machavoine F, Koezuka Y, Schneider E, et al. A distinct IL-18-induced pathway to fully activate NK T lymphocytes independently from TCR engagement. J Immunol (1999) 163(11):5871-6

18. Doisne JM, Soulard V, Becourt C, Amniai L, Henrot P, Havenar-Daughton C, et al. Cutting edge: crucial role of IL-1 and IL-23 in the innate IL-17 response of peripheral lymph node NK1.1-invariant NKT cells to bacteria. J Immunol (2011) 186(2):662-6. doi:10.4049/jimmunol.1002725

19. Nagata Y, Kamijuku H, Taniguchi M, Ziegler S, Seino K. Differential role of thymic stromal lymphopoietin in the induction of airway hyperreactivity and Th2 immune response in antigen-induced asthma with respect to natural killer T cell function. Int Arch Allergy Immunol (2007) 144(4):305-14 doi:10.1159/000106319

20. Terashima A, Watarai H, Inoue S, Sekine E, Nakagawa R, Hase K, et al. A novel subset of mouse NKT cells bearing the IL-17 receptor B responds to IL-25 and contributes to airway hyperreactivity. J Exp Med (2008) 205(12):2727-33. doi:10.1084/jem.20080698

21. Camelo A, Barlow JL, Drynan LF, Neill DR, Ballantyne SJ, Wong SH, et al. Blocking IL-25 signalling protects against gut inflammation in a type- 2 model of colitis by suppressing nuocyte and NKT derived IL-13. J Gastroenterol (2012) 47(11):1198-211. doi:10.1007/s00535-012-0591-2

22. Bourgeois E, Van LP, Samson M, Diem S, Barra A, Roga S, et al. The pro-Th2 cytokine IL-33 directly interacts with invariant NKT and NK cells to induce IFN-gamma production. Eur J Immunol (2009) 39(4):1046-55. doi:10.1002/ eji.200838575

23. Moreira-Teixeira L, Resende M, Coffre M, Devergne O, Herbeuval JP, Hermine O, et al. Proinflammatory environment dictates the IL-17-producing capacity of human invariant NKT cells. J Immunol (2011) 186(10):5758-65. doi:10.4049/jimmunol.1003043

24. Tupin E, Kinjo Y, Kronenberg M. The unique role of natural killer T cells in the response to microorganisms. Nat Rev Microbiol (2007) 5(6):405-17. doi: $10.1038 /$ nrmicro 1657

25. Michel ML, Keller AC, Paget C, Fujio M, Trottein F, Savage PB, et al. Identification of an IL-17-producing NK1.1(neg) iNKT cell population involved in airway neutrophilia. JExp Med (2007) 204(5):995-1001. doi:10.1084/jem.20061551

26. Lee YJ, Holzapfel KL, Zhu J, Jameson SC, Hogquist KA. Steady-state production of IL-4 modulates immunity in mouse strains and is determined by lineage diversity of iNKT cells. Nat Immunol (2013) 14(11):1146-54. doi:10.1038/ni.2731

27. Coquet JM, Chakravarti S, Kyparissoudis K, Mcnab FW, Pitt LA, Mckenzie BS, et al. Diverse cytokine production by NKT cell subsets and identification of 
an IL-17-producing CD4-NK1.1- NKT cell population. Proc Natl Acad Sci U S A (2008) 105(32):11287-92. doi:10.1073/pnas.0801631105

28. Benlagha K, Kyin T, Beavis A, Teyton L, Bendelac A. A thymic precursor to the NK T cell lineage. Science (2002) 296(5567):553-5. doi:10.1126/ science. 1069017

29. Van Wilgenburg B, Scherwitzl I, Hutchinson EC, Leng T, Kurioka A, Kulicke C, et al. MAIT cells are activated during human viral infections. Nat Commun (2016) 711653. doi:10.1038/ncomms11653

30. Michel ML, Lenoir C, Massot B, Diem S, Pasquier B, Sawa S, et al. SLAMassociated protein favors the development of iNKT2 over iNKT17 cells. Eur J Immunol (2016) 46(9):2162-74. doi:10.1002/eji.201646313

31. Michel ML, Mendes-Da-Cruz D, Keller AC, Lochner M, Schneider E, Dy M, et al. Critical role of ROR-gammat in a new thymic pathway leading to IL-17-producing invariant NKT cell differentiation. Proc Natl Acad Sci U S A (2008) 105(50):19845-50. doi:10.1073/pnas.0806472105

32. Webster KE, Kim HO, Kyparissoudis K, Corpuz TM, Pinget GV, Uldrich AP, et al. IL-17-producing NKT cells depend exclusively on IL-7 for homeostasis and survival. Mucosal Immunol (2014) 7(5):1058-67. doi:10.1038/mi. 2013.122

33. Engel I, Zhao M, Kappes D, Taniuchi I, Kronenberg M. The transcription factor Th-POK negatively regulates Th17 differentiation in Valpha14i NKTcells. Blood(2012) 120(23):4524-32. doi:10.1182/blood-2012-01-406280

34. Veillette A, Dong Z, Latour S. Consequence of the SLAM-SAP signaling pathway in innate-like and conventional lymphocytes. Immunity (2007) 27(5):698-710. doi:10.1016/j.immuni.2007.11.005

35. Constantinides MG, Bendelac A. Transcriptional regulation of the NKT cell lineage. Curr Opin Immunol (2013) 25(2):161-7. doi:10.1016/j. coi.2013.01.003

36. Pobezinsky LA, Etzensperger R, Jeurling S, Alag A, Kadakia T, Mccaughtry TM, et al. Let-7 microRNAs target the lineage-specific transcription factor PLZF to regulate terminal NKT cell differentiation and effector function. Nat Immunol (2015) 16(5):517-24. doi:10.1038/ni.3146

37. Thapa P, Manso B, Chung JY, Romera Arocha S, Xue HH, Angelo DBS, et al. The differentiation of ROR-gammat expressing iNKT17 cells is orchestrated by Runx1. Sci Rep (2017) 7(1):7018. doi:10.1038/s41598-017-07365-8

38. Vicari A, De Moraes Mdo C, Gombert JM, Dy M, Penit C, Papiernik M, et al. Interleukin 7 induces preferential expansion of $\mathrm{V}$ beta $8.2+\mathrm{CD} 4-8$ - and $\mathrm{V}$ beta $8.2+\mathrm{CD} 4+8$ - murine thymocytes positively selected by class I molecules. J Exp Med (1994) 180(2):653-61. doi:10.1084/jem.180.2.653

39. Gumperz JE, Miyake S, Yamamura T, Brenner MB. Functionally distinct subsets of CD1d-restricted natural killer T cells revealed by CD1d tetramer staining. J Exp Med (2002) 195(5):625-36. doi:10.1084/jem.20011786

40. Barral P, Sanchez-Nino MD, Van Rooijen N, Cerundolo V, Batista FD. The location of splenic NKT cells favours their rapid activation by blood-borne antigen. EMBO J (2012) 31(10):2378-90. doi:10.1038/emboj.2012.87

41. Geissmann F, Cameron TO, Sidobre S, Manlongat N, Kronenberg M, Briskin MJ, et al. Intravascular immune surveillance by CXCR6+ NKT cells patrolling liver sinusoids. PLoS Biol (2005) 3(4):e113. doi:10.1371/journal. pbio.0030113

42. Scanlon ST, Thomas SY, Ferreira CM, Bai L, Krausz T, Savage PB, et al. Airborne lipid antigens mobilize resident intravascular NKT cells to induce allergic airway inflammation. J Exp Med (2011) 208(10):2113-24. doi:10.1084/ jem.20110522

43. Liew PX, Kubes P. Intravital imaging - dynamic insights into natural killer T cell biology. Front Immunol (2015) 6:240. doi:10.3389/fimmu.2015.00240

44. Van Kaer L, Parekh VV, Wu L. The response of CD1d-restricted invariant NKT cells to microbial pathogens and their products. Front Immunol (2015) 6:226. doi:10.3389/fimmu.2015.00226

45. Belo R, Santarem N, Pereira C, Perez-Cabezas B, Macedo F, Leite-DeMoraes M, et al. Leishmania infantum exoproducts inhibit human invariant NKT cell expansion and activation. Front Immunol (2017) 8:710. doi:10.3389/ fimmu.2017.00710

46. Brown DR, Fowell DJ, Corry DB, Wynn TA, Moskowitz NH, Cheever AW, et al. Beta 2-microglobulin-dependent NK1.1+ T cells are not essential for T helper cell 2 immune responses. J Exp Med (1996) 184(4):1295-304. doi:10.1084/jem.184.4.1295

47. Korsgren M, Persson CG, Sundler F, Bjerke T, Hansson T, Chambers BJ, et al. Natural killer cells determine development of allergen-induced eosinophilic airway inflammation in mice. J Exp Med (1999) 189(3):553-62. doi:10.1084/ jem.189.3.553

48. Zhang Y, Rogers KH, Lewis DB. Beta 2-microglobulin-dependent T cells are dispensable for allergen-induced T helper 2 responses. J Exp Med (1996) 184(4):1507-12. doi:10.1084/jem.184.4.1507

49. Treiner E, Duban L, Bahram S, Radosavljevic M, Wanner V, Tilloy F, et al. Selection of evolutionarily conserved mucosal-associated invariant $\mathrm{T}$ cells by MR1. Nature (2003) 422(6928):164-9. doi:10.1038/nature01433

50. Lisbonne M, Diem S, De Castro Keller A, Lefort J, Araujo LM, Hachem P, et al. Cutting edge: invariant $\mathrm{V}$ alpha 14 NKT cells are required for allergeninduced airway inflammation and hyperreactivity in an experimental asthma model. J Immunol (2003) 171(4):1637-41. doi:10.4049/jimmunol.171.4.1637

51. Akbari O, Stock P, Meyer E, Kronenberg M, Sidobre S, Nakayama T, et al. Essential role of NKT cells producing IL-4 and IL-13 in the development of allergen-induced airway hyperreactivity. Nat Med (2003) 9(5):582-8. doi:10.1038/nm851

52. Das J, Eynott P, Jupp R, Bothwell A, Van Kaer L, Shi Y, et al. Natural killer $\mathrm{T}$ cells and $\mathrm{CD} 8+\mathrm{T}$ cells are dispensable for $\mathrm{T}$ cell-dependent allergic airway inflammation. Nat Med (2006) 12(12):1345-6; author reply 7. doi:10.1038/ nm1206-1345

53. Skold M, Faizunnessa NN, Wang CR, Cardell S. CD1d-specific NK1.1+ $\mathrm{T}$ cells with a transgenic variant TCR. JImmunol (2000) 165(1):168-74. doi:10.4049/jimmunol.165.1.168

54. Jahng A, Maricic I, Aguilera C, Cardell S, Halder RC, Kumar V. Prevention of autoimmunity by targeting a distinct, noninvariant CD1d-reactive T cell population reactive to sulfatide. J Exp Med (2004) 199(7):947-57. doi:10.1084/jem.20031389

55. Whitehead GS, Walker JK, Berman KG, Foster WM, Schwartz DA. Allergeninduced airway disease is mouse strain dependent. Am J Physiol Lung Cell Mol Physiol (2003) 285(1):L32-42. doi:10.1152/ajplung.00390.2002

56. Chandra S, Zhao M, Budelsky A, De Mingo Pulido A, Day J, Fu Z, et al. A new mouse strain for the analysis of invariant NKT cell function. Nat Immunol (2015) 16(8):799-800. doi:10.1038/ni.3203

57. Olszak T, An D, Zeissig S, Vera MP, Richter J, Franke A, et al. Microbial exposure during early life has persistent effects on natural killer $\mathrm{T}$ cell function. Science (2012) 336(6080):489-93. doi:10.1126/science.1219328

58. An D, Oh SF, Olszak T, Neves JF, Avci FY, Erturk-Hasdemir D, et al. Sphingolipids from a symbiotic microbe regulate homeostasis of host intestinal natural killer T cells. Cell (2014) 156(1-2):123-33. doi:10.1016/j. cell.2013.11.042

59. Hachem P, Lisbonne M, Michel ML, Diem S, Roongapinun S, Lefort J, et al. Alpha-galactosylceramide-induced iNKT cells suppress experimental allergic asthma in sensitized mice: role of IFN-gamma. Eur J Immunol (2005) 35(10):2793-802. doi:10.1002/eji.200535268

60. Matangkasombut P, Pichavant M, Yasumi T, Hendricks C, Savage PB, Dekruyff RH, et al. Direct activation of natural killer T cells induces airway hyperreactivity in nonhuman primates. JAllergy Clin Immunol (2008) 121(5):1287-9. doi:10.1016/j.jaci.2008.02.006

61. Damayanti T, Kikuchi T, Zaini J, Daito H, Kanehira M, Kohu K, et al. Serial OX40 engagement on CD4+ T cells and natural killer T cells causes allergic airway inflammation. Am J Respir Crit Care Med (2010) 181(7):688-98. doi:10.1164/rccm.200910-15980C

62. Albacker LA, Chaudhary V, Chang YJ, Kim HY, Chuang YT, Pichavant M, et al. Invariant natural killer $\mathrm{T}$ cells recognize a fungal glycosphingolipid that can induce airway hyperreactivity. Nat Med (2013) 19(10):1297-304. doi: $10.1038 / \mathrm{nm} .3321$

63. Moore WC, Hastie AT, Li X, Li H, Busse WW, Jarjour NN, et al. Sputum neutrophil counts are associated with more severe asthma phenotypes using cluster analysis. J Allergy Clin Immunol (2014) 133(6):1557-63.e5. doi:10.1016/j.jaci.2013.10.011

64. Pavord ID, Beasley R, Agusti A, Anderson GP, Bel E, Brusselle G, et al. After asthma: redefining airways diseases. Lancet (2018) 391(10118):350-400. doi:10.1016/S0140-6736(17)30879-6

65. Ray A, Kolls JK. Neutrophilic inflammation in asthma and association with disease severity. Trends Immunol (2017) 38(12):942-54. doi:10.1016/j. it.2017.07.003

66. Pichavant M, Goya S, Meyer EH, Johnston RA, Kim HY, Matangkasombut P, et al. Ozone exposure in a mouse model induces airway hyperreactivity that 
requires the presence of natural killer T cells and IL-17. J Exp Med (2008) 205(2):385-93. doi:10.1084/jem.20071507

67. Shim JU, Koh YI. Increased Th2-like invariant natural killer T cells in peripheral blood from patients with asthma. Allergy Asthma Immunol Res (2014) 6(5):444-8. doi:10.4168/aair.2014.6.5.444

68. Akbari O, Faul JL, Hoyte EG, Berry GJ, Wahlstrom J, Kronenberg M, et al. $\mathrm{CD} 4+$ invariant T-cell-receptor+ natural killer T cells in bronchial asthma. N Engl J Med (2006) 354(11):1117-29. doi:10.1056/NEJMoa053614

69. Vijayanand P, Seumois G, Pickard C, Powell RM, Angco G, Sammut D, et al. Invariant natural killer $\mathrm{T}$ cells in asthma and chronic obstructive pulmonary disease. N Engl J Med (2007) 356(14):1410-22. doi:10.1056/ NEJMoa064691

70. Thomas SY, Chyung YH, Luster AD. Natural killer T cells are not the predominant $\mathrm{T}$ cell in asthma and likely modulate, not cause, asthma. J Allergy Clin Immunol (2010) 125(5):980-4. doi:10.1016/j.jaci.2010.01.032

71. Thomas SY, Lilly CM, Luster AD. Invariant natural killer T cells in bronchial asthma. N Engl J Med (2006) 354(24):2613-6; author reply-6. doi:10.1056/ NEJMc066189

72. Matangkasombut P, Marigowda G, Ervine A, Idris L, Pichavant M, Kim HY, et al. Natural killer T cells in the lungs of patients with asthma. J Allergy Clin Immunol (2009) 123(5):1181-5. doi:10.1016/j.jaci.2009.02.013

73. Pham-Thi N, De Blic J, Le Bourgeois M, Dy M, Scheinmann P, Leite-DeMoraes MC. Enhanced frequency of immunoregulatory invariant natural killer T cells in the airways of children with asthma. J Allergy Clin Immunol (2006) 117(1):217-8. doi:10.1016/j.jaci.2005.09.052

74. Koh YI, Shim JU. Association between sputum natural killer T cells and eosinophilic airway inflammation in human asthma. Int Arch Allergy Immunol (2010) 153(3):239-48. doi:10.1159/000314364

75. Lezmi G, Abou Taam R, Dietrich C, Chatenoud L, De Blic J, Leite-DeMoraes M. Circulating IL-17-producing mucosal-associated invariant T cells (MAIT) are associated with symptoms in children with asthma. Clin Immunol (2018) 188:7-11. doi:10.1016/j.clim.2017.11.009

76. Chandra S, Wingender G, Greenbaum JA, Khurana A, Gholami AM, Ganesan AP, et al. Development of asthma in inner-city children: possible roles of MAIT cells and variation in the home environment. J Immunol (2018) 200(6):1995-2003. doi:10.4049/jimmunol.1701525

77. Le Bourhis L, Dusseaux M, Bohineust A, Bessoles S, Martin E, Premel V, et al. MAIT cells detect and efficiently lyse bacterially-infected epithelial cells. PLoS Pathog (2013) 9(10):e1003681. doi:10.1371/journal.ppat.1003681

78. Kjer-Nielsen L, Patel O, Corbett AJ, Le Nours J, Meehan B, Liu L, et al. MR1 presents microbial vitamin B metabolites to MAIT cells. Nature (2012) 491(7426):717-23. doi:10.1038/nature11605

79. Koay HF, Gherardin NA, Enders A, Loh L, Mackay LK, Almeida CF, et al. A three-stage intrathymic development pathway for the mucosal-associated invariant T cell lineage. Nat Immunol (2016) 17(11):1300-11. doi:10.1038/ ni. 3565

80. Lee OJ, Cho YN, Kee SJ, Kim MJ, Jin HM, Lee SJ, et al. Circulating mucosalassociated invariant $\mathrm{T}$ cell levels and their cytokine levels in healthy adults. Exp Gerontol (2014) 49:47-54. doi:10.1016/j.exger.2013.11.003

81. Lepore M, Kalinichenko A, Colone A, Paleja B, Singhal A, Tschumi A, et al. Parallel T-cell cloning and deep sequencing of human MAIT cells reveal stable oligoclonal TCRbeta repertoire. Nat Commun (2014) 5:3866. doi:10.1038/ncomms4866

82. Kurioka A, Jahun AS, Hannaway RF, Walker LJ, Fergusson JR, SverremarkEkstrom E, et al. Shared and distinct phenotypes and functions of human CD161++ valpha7.2+ T cell subsets. Front Immunol (2017) 8:1031. doi:10.3389/fimmu.2017.01031

83. Rahimpour A, Koay HF, Enders A, Clanchy R, Eckle SB, Meehan B, et al. Identification of phenotypically and functionally heterogeneous mouse mucosal-associated invariant T cells using MR1 tetramers. J Exp Med (2015) 212(7):1095-108. doi:10.1084/jem.20142110

84. Reantragoon R, Corbett AJ, Sakala IG, Gherardin NA, Furness JB, Chen Z, et al. Antigen-loaded MR1 tetramers define T cell receptor heterogeneity in mucosal-associated invariant T cells. J Exp Med (2013) 210(11):2305-20. doi:10.1084/jem.20130958

85. Martin E, Treiner E, Duban L, Guerri L, Laude H, Toly C, et al. Stepwise development of MAIT cells in mouse and human. PLoS Biol (2009) 7(3):e54. doi:10.1371/journal.pbio.1000054
86. Dias J, Leeansyah E, Sandberg JK. Multiple layers of heterogeneity and subset diversity in human MAIT cell responses to distinct microorganisms and to innate cytokines. Proc Natl Acad Sci U S A (2017) 114(27):E5434-43. doi:10.1073/pnas.1705759114

87. Wallington JC, Williams AP, Staples KJ, Wilkinson TMA. IL-12 and IL-7 synergize to control mucosal-associated invariant T-cell cytotoxic responses to bacterial infection. J Allergy Clin Immunol (2018) 141(6):2182-95.e6. doi:10.1016/j.jaci.2017.08.009

88. Tang XZ, Jo J, Tan AT, Sandalova E, Chia A, Tan KC, et al. IL-7 licenses activation of human liver intrasinusoidal mucosal-associated invariant $\mathrm{T}$ cells. J Immunol (2013) 190(7):3142-52. doi:10.4049/jimmunol.1203218

89. Dusseaux M, Martin E, Serriari N, Peguillet I, Premel V, Louis D, et al. Human MAIT cells are xenobiotic-resistant, tissue-targeted, CD161hi IL-17-secreting T cells. Blood (2011) 117(4):1250-9. doi:10.1182/ blood-2010-08-303339

90. Salou M, Franciszkiewicz K, Lantz O. MAIT cells in infectious diseases. Curr Opin Immunol (2017) 48:7-14. doi:10.1016/j.coi.2017.07.009

91. Greene JM, Dash P, Roy S, Mcmurtrey C, Awad W, Reed JS, et al. MR1restricted mucosal-associated invariant $\mathrm{T}$ (MAIT) cells respond to mycobacterial vaccination and infection in nonhuman primates. Mucosal Immunol (2017) 10(3):802-13. doi:10.1038/mi.2016.91

92. Chen Z, Wang H, D'souza C, Sun S, Kostenko L, Eckle SB, et al. Mucosalassociated invariant $\mathrm{T}$-cell activation and accumulation after in vivo infection depends on microbial riboflavin synthesis and co-stimulatory signals. Mucosal Immunol (2017) 10(1):58-68. doi:10.1038/mi.2016.39

93. Gold MC, Cerri S, Smyk-Pearson S, Cansler ME, Vogt TM, Delepine J, et al. Human mucosal associated invariant $\mathrm{T}$ cells detect bacterially infected cells. PLoS Biol (2010) 8(6):e1000407. doi:10.1371/journal.pbio.1000407

94. Le Bourhis L, Martin E, Peguillet I, Guihot A, Froux N, Core M, et al. Antimicrobial activity of mucosal-associated invariant T cells. Nat Immunol (2010) 11(8):701-8. doi:10.1038/ni.1890

95. Loh L, Wang Z, Sant S, Koutsakos M, Jegaskanda S, Corbett AJ, et al. Human mucosal-associated invariant $\mathrm{T}$ cells contribute to antiviral influenza immunity via IL-18-dependent activation. Proc Natl Acad Sci U S A (2016) 113(36):10133-8. doi:10.1073/pnas.1610750113

96. Baron M, Belo R, Cathelin D, Moreira-Teixeira L, Cartery C, Rondeau E, et al. Innate-like and conventional $\mathrm{T}$ cell populations from hemodialyzed and kidney transplanted patients are equally compromised. PLoS One (2014) 9(8):e105422. doi:10.1371/journal.pone.0105422

97. Fazekas B, Moreno-Olivera A, Kelly Y, O'hara P, Murray S, Kennedy A, et al. Alterations in circulating lymphoid cell populations in systemic small vessel vasculitis are non-specific manifestations of renal injury. Clin Exp Immunol (2018) 191(2):180-8. doi:10.1111/cei.13058

98. Gherardin NA, Loh L, Admojo L, Davenport AJ, Richardson K, Rogers A, et al. Enumeration, functional responses and cytotoxic capacity of MAIT cells in newly diagnosed and relapsed multiple myeloma. Sci Rep (2018) 8(1):4159. doi:10.1038/s41598-018-22130-1

99. Magalhaes I, Pingris K, Poitou C, Bessoles S, Venteclef N, Kiaf B, et al. Mucosal-associated invariant $\mathrm{T}$ cell alterations in obese and type 2 diabetic patients. J Clin Invest (2015) 125(4):1752-62. doi:10.1172/JCI78941

100. Serriari NE, Eoche M, Lamotte L, Lion J, Fumery M, Marcelo P, et al. Innate mucosal-associated invariant T (MAIT) cells are activated in inflammatory bowel diseases. Clin Exp Immunol (2014) 176(2):266-74. doi:10.1111/cei. 12277

101. Ben Youssef G, Tourret M, Salou M, Ghazarian L, Houdouin V, Mondot $\mathrm{S}$, et al. Ontogeny of human mucosal-associated invariant $\mathrm{T}$ cells and related T cell subsets. J Exp Med (2018) 215(2):459-79. doi:10.1084/ jem.20171739

102. Hinks TS, Zhou X, Staples KJ, Dimitrov BD, Manta A, Petrossian T, et al. Innate and adaptive $\mathrm{T}$ cells in asthmatic patients: relationship to severity and disease mechanisms. JAllergy Clin Immunol (2015) 136(2):323-33. doi:10.1016/j.jaci.2015.01.014

103. Keller AN, Eckle SB, Xu W, Liu L, Hughes VA, Mak JY, et al. Drugs and druglike molecules can modulate the function of mucosal-associated invariant T cells. Nat Immunol (2017) 18(4):402-11. doi:10.1038/ni.3679

104. Reeder KM, Dunaway CW, Blackburn JP, Yu Z, Matalon S, Hastie AT, et al. The common gamma-chain cytokine IL-7 promotes immunopathogenesis during fungal asthma. Mucosal Immunol (2018). doi:10.1038/s41385-018-0028-1 
105. Wisniewski JA, Muehling LM, Eccles JD, Capaldo BJ, Agrawal R, Shirley DA, et al. TH1 signatures are present in the lower airways of children with severe asthma, regardless of allergic status. J Allergy Clin Immunol (2018) 141(6):2048-60.e13. doi:10.1016/j.jaci.2017.08.020

106. Rouxel O, Da Silva J, Beaudoin L, Nel I, Tard C, Cagninacci L, et al. Cytotoxic and regulatory roles of mucosal-associated invariant $\mathrm{T}$ cells in type 1 diabetes. Nat Immunol (2017) 18(12):1321-31. doi:10.1038/ni.3854

107. Irvin C, Zafar I, Good J, Rollins D, Christianson C, Gorska MM, et al. Increased frequency of dual-positive TH2/TH17 cells in bronchoalveolar lavage fluid characterizes a population of patients with severe asthma. J Allergy Clin Immunol (2014) 134(5):1175-86.e7. doi:10.1016/j.jaci.2014.05.038

108. Chambers ES, Nanzer AM, Pfeffer PE, Richards DF, Timms PM, Martineau AR, et al. Distinct endotypes of steroid-resistant asthma characterized by IL-17A(high) and IFN-gamma(high) immunophenotypes: potential benefits of calcitriol. J Allergy Clin Immunol (2015) 136(3):628-37. e4. doi:10.1016/j.jaci.2015.01.026

109. Lezmi G, Leite-De-Moraes M. Comment on "Development of asthma in inner-city children: possible roles of MAIT cells and variation in the home environment”. J Immunol (2018) 200(10):3317. doi:10.4049/ jimmunol.1800344

110. Chandra S, Wingender G, Greenbaum JA, Kronenberg M. Response to comment on "development of asthma in inner-city children: possible roles of MAIT cells and variation in the home environment". J Immunol (2018) 200(10):3317-8. doi:10.4049/jimmunol.1800397

Conflict of Interest Statement: The authors declare that the research was conducted in the absence of any commercial or financial relationships that could be construed as a potential conflict of interest.

Copyright (c) 2018 Lezmi and Leite-de-Moraes. This is an open-access article distributed under the terms of the Creative Commons Attribution License (CC BY). The use, distribution or reproduction in other forums is permitted, provided the original author(s) and the copyright owner(s) are credited and that the original publication in this journal is cited, in accordance with accepted academic practice. No use, distribution or reproduction is permitted which does not comply with these terms. 